The Canadian Journal of Higher Education

La revue canadienne d'enseignement supérieur

Volume XXXI, No. 2, 2001 pages $135-166$

\title{
'Academia Inc.': \\ The Perspective of University Presidents
}

\section{JOAN MOUNT \& CHARLES BÉLANGER}

Laurentian University

\section{ABSTRACT}

With the erosion of public funding, Canadian universities have increasingly diversified their funding base. An upsurge of entrepreneurial initiatives has displayed significant earmarks of privatization which have alarmed some faculty and student stakeholders, drawing reactions particularly from among those from the arts domains. They accuse senior university administrative officers of distorting academic values. This study is an attempt to capture and understand the views of presidents of Canadian universities $(\mathrm{N}=89)$ through a 60 -item questionnaire focused in broad terms on academic values, funding, institutional directions, and the impact of the corporate sector.

\section{RÉSUMÉ}

À cause de l'érosion des fonds publics, les universités canadiennes ont dû diversifier leur base de financement. Ce nouvel esprit d'entrepreneuriat a donné des signes marqués de privatisation qui ont provoqué des remous dans certains groupes de professeurs et d'étudiants, et surtout ceux appartenant au domaine des arts. Les contestataires accusent la haute administration des établissements de

* The authors wish to express their gratitude to the reviewers for their detailed and perceptive comments on an earlier draft. 
déformer les valeurs universitaires. Cette étude a tenté de cerner et de comprendre les points de vue des recteurs canadiens $(\mathrm{N}=89)$ au moyen d'un questionnaire portant sur 60 points concernant les valeurs, le financement, les orientations universitaires de même que l'influence du secteur des entreprises.

\section{INTRODUCTION}

The past two decades have seen universities operate increasingly in an environment of diminished financial support from government, amid escalating demands on their resources. They find themselves in a situation marked by government deficit control, heavier demands on the public purse, and competing priorities for government support. Consequently, most institutions of higher learning point to a decreasing ability to sustain ongoing obligations, and less latitude to develop new initiatives. Expected to maintain as always the institutional and academic heritage, to develop quickly and flexibly new fields of study and modes of thought, and to embrace the contradictory demands of a rising number of stakeholders (Clark, 1998a, 1998b), universities have increasingly perceived themselves faced with a choice: either prune some of their core activities or become "entrepreneurial." In varying degree they have opted for the latter course.

Dramatic declines in government financial support during the $1990 \mathrm{~s}$ seem to have been the culminating phase of a 20 -year trend that saw per student funding fall by $36 \%$. Concurrently, full-time student enrollment has expanded by $50 \%$ (Association of Universities and Colleges of Canada [AUCC], 1999), tuition fees have increased roughly $390 \%$ (Statistics Canada, 1999), and per student debt at completion has skyrocketed to an average of $\$ 25,000 \mathrm{CAD}$, as reported by Canada Student Loan officials. Today, universities command a smaller operating revenue base in current dollars than at the start of the nineties (AUCC, 1999). To bridge the funding gap, universities have not only had to raise tuition fees by substantial amounts, but also they have perceived the need to forge corporate partnerships, name buildings after benefactors, channel 
private money into high-profile programs, and reshape research to respond to the explicit interests of the private sector (Dwyer, 1997).

This newly manifested entrepreneurship, as some call it (e.g., Fairweather, 1988), has attracted the attention of critics in academia, in Canada and elsewhere (e.g., Currie \& Newson, 1998; Etzkowitz \& Leydesdorff, 1997; Marginson, 1997; Slaughter \& Leslie, 1997; Soley, 1996), who feel disquieted by what they perceive as the quick transformation of universities into bottom-line profit centres. They hold the view that long-standing academic values have been gravely eroded. Concerned academics here in Canada claim that senior administrators are fostering the creation of "Academia Incorporated" by letting corporate stakeholders with deep pockets dictate university directions and instill market-driven values (Buchbinder \& Newson, 1990; Buchbinder \& Rajagopal, 1993, 1995; Newson 1994; Newson \& Buchbinder, 1988).

At a greater level of detail, senior administrative officers are notably the targets of allegations which include the following: (1) turning postsecondary education away from a public right to an elitist consumer product; (2) widening the gap between support for the arts-oriented disciplines on the one hand and the more business/technology-focused programs on the other, mostly in the name of global competitiveness; (3) veering the research agenda from basic, curiosity-driven questions and serendipitous discoveries to a saleable product immediately relevant to the private sector; (4) creating a two-tiered university system composed of well-established and well-to-do research-intensive schools at one pole and small, regional, and primarily teaching-focused institutions at the other; and (5) giving undue precedence to free market and wealth creation tenets at the expense of core academic values such as autonomy, collegiality, and free thinking. University presidents have doubtless encountered challenges to defend decisions at the local level regarding specific issues.

How do the leaders of institutions of higher learning respond to these economic and societal perspectives? In attempting to do so, do they willfully compromise the long-standing defining characteristics of universities: institutional autonomy, academic freedom, intellectual development, transmittal of values, truth-seeking for its own sake? The 
latter section of this article speaks to the views of Canadian university presidents toward some of these competing imperatives. As a group of executives shaping the future of universities in Canada, their commitment to the well-being of their institutions is not called into question. Nonetheless, where they stand on the marketization of university products and services is not known. This study has as its objective to capture and report on their stance as a group on questions associated with the phenomenon that has been dubbed "Academia Inc." (Dwyer, 1998). Employing the now familiar typology used by Maclean's magazine, it undertakes, as well, to explore how much dispersion exists in the views held by heads of different types of university. It also investigates differences, if any, relative to geographical situation.

\section{BACKGROUND}

\section{Entrepreneurship: Not a Choice but a Necessity?}

The cause-and-effect relationship of government cutbacks in higher education took two decades to shape itself, and in doing so it has created formidable challenges to university presidents and their senior administrative officers. From a high of $80 \%$ in direct public funding, universities now receive below $60 \%$ of their operating budgets from governments, the rest coming from tuition fees (20\%) augmented by a host of other income-generating activities such as the sale of services and products, investment income, bequests and corporate donations (Canadian Association of University Business Officers [CAUBO], 1999). However, despite substantial increases in tuition fees, universities face funding shortages. Fees at present cover almost $40 \%$ of the operating costs in half of Canada's universities, yet they serve to offset only $50 \%$ of government support lost since 1990 . This is particularly the case for institutions focused on arts and science programs (AUCC, 1999). The departure of universities from a relatively sheltered, if not government-privileged, environment has forced their presidents and senior administrative officers to look outward for new collaborative arrangements to offset the effects. 
Government cutbacks are arguably the direct cause of the impetus to define a new paradigm - characterized to a growing degree by universities vying for industry-relevant research, technologically innovative programs, user-pay services, and patrons capable of contributing to rising costs.The changing nature of university funding, reflected mainly in the partial withdrawal of the federal government from both the funding and execution of research, has a corollary: universities are more and more often invited by government funding bodies to seek partnerships with the private sector. An insistent connection is articulated between knowledge, innovation, and research and development, on the one hand, and the country's economic competitiveness on the other. Discussion of this relationship figures prominently in the science policy debate (AUCC, 1999 , p. 80). The federal government has assumed an enabling role through various "challenge and matching" programs such as those offered under the umbrella of the Canada Foundation for Innovation (i.e., tying public support for research to support from corporate partners). It offers strategic investments in areas deemed critical to the country`s productivity and competitiveness, hence forcing universities to forge alliances with external partners. Some provincial governments have adopted the same approach, in part to leverage this federal money. By 1998, there were an estimated 300 university spin-offs in fields related mostly to science, technology, environment, and health (Grigoroff, 1998). "The growing orientation of university research toward industry is the most exciting development of the fin de siècle," declared the president of the Canadian Institute for Advanced Research, while also warning that the government must not dodge its responsibility to support basic research because, in the absence of such activity, new products could not emerge (Dupré, 1998).

Clearly, government actions are affected by global trends. Canadian competitiveness, triggered by free trade agreements, had become the catalyst for more conservative economic and social policies as reflected in the urgency of reducing government deficits, overhauling the unemployment insurance system, and training the labour force (Abele, 1992). The private sector began striving painfully to restructure by cutting production and inventory costs, and focussing increasingly on global markets. 
Opening up to international market forces was not seen as an option: it was marketed as being in the interest of all citizens (Johnson, McBride \& Smith, 1994). The public in general had warmed up to the idea that government and publicly funded organizations have lived too long beyond their means, that it was time for greater accountability, and that more emphasis should be placed on free market forces. Politicians of late, initially in countries other than Canada (e.g., Margaret Thatcher in the United Kingdom, Ronald Reagan in the United States) and now in Canada (e.g., Mike Harris in Ontario) have been elected on promises of making the government smaller and of running it like a business. Public organizations are asked to do more with less.

Further to the global context, universities have experienced unprecedented pressures, other than strictly fiscal, to show more sensitivity to Canada's competitive needs in terms of the human capital required in areas of science and technology. Statements such as the one below exemplify this current:

...the mix of education and training programs [does] not match labour market needs as well as it might. For example, while there is no gap in the capacity of the province's universities and university colleges to produce the number of university graduates that will be required, there appears to be a relative over-supply of graduates in academic programs and an under-supply of those in applied. (British Columbia Labour Force Development Board, 1995, p. 43)

A recent policy document (Government of Québec, 1996) expressed the need to establish closer ties between education and the workplace. It stated that real requirements of the labour market should be met, that education should be more relevant (our emphasis) and should help graduates to step into the workplace. Obviously, the public discourse has become more utilitarian and vocational. Further, financial rewards are increasingly used to encourage inter-institutional cooperation between colleges and universities, as well as differentiation and collaboration among the latter (Fisher \& Rubenson, 1998).

Finally, AUCC (1999) reports that a number of public opinion polls indicated solid support for postsecondary education as an individual and 
collective engine to enhance quality of life and competitiveness of Canadian workers, but that "there is also increasing awareness that higher education yields high private returns, [and] that people believe students should bear some of the costs of their education" (p. 28). Hence there is now more public support for "user-pay" initiatives and differential fees, particularly in programs which are known to be quick and steady income generators for graduates. Also, even though Canada has one of the highest proportions of young people enrolled in universities, the chief beneficiaries of publicly subsidized education are middle- and upper-middle-class families (The Globe and Mail, 1999).

\section{The Arguments Against Corporate-Style University Entrepreneurship}

The new economic imperative that links higher education and research with work-related training and national economic competitiveness has engendered a clash between opposing and competing ideologies and interests. Critics within the universities contend that these institutions are selling their prestige and knowledge-creation capability for very little monetary return. It is known that the amount of revenue generated by entrepreneurial relationships is small relative to other sources of university funding. Moreover, the amount pales in comparison to the magnitude of the cutbacks The criticism goes that universities have succumbed to policies and practices that foster managerialism, elitism, vocationalism, accountability, and privatization. Stated bluntly, there has been a shift toward business values, a market agenda, and a barrier to entry for people from lower socio-economic strata. It is argued that those business values have also led to insularity among academics, greater closed individualism, a lessened sense or loss of community - in short the precedence of dehumanizing aspects of global markets over community and human priorities (Currie, 1998; Dudley, 1998).

More specifically, critics assert that universities exist to provide an opportunity to explore the intellectual world as well as to prepare people for the workforce (Fisher \& Rubenson, 1998). The more extreme objectors question the linkages between educational institutions and work, pointing to the fact that universities have abdicated their long-standing 
commitment to the ethos of liberal education. Some critics contend that senior administrative officers are blatantly inconsistent when, on the one hand, they advocate generic skills such as the ability to change, to think, to solve problems, to be independent, and to communicate, and when, on the other hand, they encourage new training responsibilities which have traditionally been devolved to colleges, particularly in technology and business-related fields (Fisher \& Rubenson, 1998).

It's an enormous error to believe that technology can somehow be the content of education. Technical training is training in what is sure to be obsolete soon anyway; it's self defeating, and it won't get you through the next 60 years of your life. (John Ralston Saul, as quoted in Fallis, 1999. p. 7)

There is a contention, too, that universities are becoming more like colleges and vice-versa. As the distinction between universities and colleges becomes less clear, questions ensue about institutional missions, the role and substance of academic work by the faculty, and issues pertaining to individual and institutional autonomy. A related perspective is that market-driven values will accentuate differences among universities themselves. In several provinces, policy documents have been prepared to make the tiering of universities more defined (Government of Québec, 1996; Manitoba University Education Review Commission, 1993; Nova Scotia Council on Higher Education, 1996). Because such plans would encourage certain universities to specialize in research whereas others would focus on undergraduate studies, institutions in the latter category have resisted this distinction. Such a hierarchy would put research and graduate studies largely out of reach for this second group. The idea that some universities are "research intensive" has always been an offensive notion to those presidents who head institutions not generally identified as such. They resist the prospect of their institutional missions being thus differentiated, and hence circumscribed in this way. Further, a number of faculty members are also unsettled by talks of changing the nature of their academic work.

Should the balance among teaching, research, and community service be altered? If so, what form of differentiation in roles would be appropriate? Should it be at the level of institution, 
academic unit, or individual faculty member? Should the funding allocation system be changed to enable any such shifts? (Ontario Council on University Affairs, 1995, p. 72).

Some faculty members feel that there has been a corporatization of universities that makes the collegial model increasingly peripheral to the decision-making process of their own institutions. As a corollary, their work conditions have deteriorated in the following ways: they are supervised more closely; their teaching loads have increased; they are burdened by numerous accountability reports; and their control over their institutions has become minimal (Cassin \& Morgan, 1992; Currie, 1998; Currie \& Vidovich, 1998; Newson, 1992, 1998). They express the view that institutional autonomy has been compromised by business opportunities and utilitarianism, while undermining their academic freedom at the same time (Tapper \& Salter, 1995). In particular, they point to the privileging of science in research and development and technology policy, and the associated influence on curriculum policy within their institutions.Social critics outside as well as inside academia warn of the pitfalls associated with the new relations between government/corporation and academic research (Polster, 1994), and the increasing commercialization of universities, particularly in the applied research areas. The most prominent incident in Canada relates to the Olivieri-Apotex affair (Shuchman, 1998), in which an agreement of non-disclosure had been signed between the researcher and the sponsoring company. When research findings were at odds with the company's expectations and commercialization intentions, the researcher felt responsible to divulge the results to protect the public; hence the furor by the company, the question of academic freedom for the researcher, and the issue of the integrity of the university. The recent Report of the Expert Panel on the Commercialization of University Research (ACST, 1999) commissioned by the Prime Minister's Advisory Council on Science and Technology has intensified the debate about intellectual property and commercialization of discoveries and inventions, particularly among social scientists (CAUT, 1999). Finally, there are concerns around the lessened accessibility of university education to potential students, an outcome of rising fees. The Canadian university system has always been a relatively 
homogeneous public system committed to egalitarianism rather than elitism, as expressed in low fees. Despite financial assistance strategies, the increasingly steep price tag of a university education is seen to be a mounting barrier for students from less affluent backgrounds.

\section{DESIGN AND METHOD}

A one-page, 12-question survey was sent to the heads of all $89 \mathrm{mem}$ ber universities within the Association of Universities and Colleges of Canada (AUCC). This research instrument was designed to canvass the opinions and attitudes of university presidents on 60 specific items ranging across tuition fees, operating budgets, impact of corporate involvement on programs and research agendas, campus environment, institutional directions, effect of government "challenge and matching" research opportunities, and emerging academic and managerial imperatives. The principal measurement technique was a five-point semantic differential scale (Likert or Likert-like) used to find out whether respondents endorsed particular views. Use was made also of the constant-sum scale which asks the respondents to weigh the relative importance of certain attributes by dividing a constant sum among them. In this survey, the sums to be broken down were expressed in percentages totalling to $100 \%$. Each respondent was requested to identify whether his/her institution is a "Medical/Doctoral university," a "Comprehensive university," or a "Primarily Undergraduate university." Canadian university circles are familiar with this classification since Maclean's, a national magazine, has ranked universities annually for the last nine years employing this terminology. Moreover, respondents were asked to indicate whether their universities were located in one of four metropolitan areas in which there is a concentration of universities; these urban areas are Vancouver, Toronto, Montréal, and Halifax. Over the last 50 years, a number of international studies (De la Mothe, 1998; Florida, 1995; Lacroix \& Martin, 1987, 1988; Maillat \& Vasserot, 1986; Schumpeter, 1954) show consistently that large educational and industrial agglomerations have been more conducive to the creation of research opportunities on the basis of critical mass, economies of scale, a "pressure cooker" 
atmosphere, international recognition, and productivity. Isolating universities in the large urban centres as a cluster within the overall group was therefore thought to be of interest, particularly in terms of attitudes toward technology and business-friendly environment.The data were analysed from three different perspectives. First, respondents were treated as an all-inclusive group to discover the prevailing views of the entire population of university presidents. This analysis was accomplished by way of descriptive statistics which generally took the form of means obtained from weights assigned on the five-point semantic differential scale $(1=$ very positive $\backslash$ strongly agree... up to $5=$ very negativelstrongly disagree). Second, the data were examined according to university type (Medical/Doctoral, Comprehensive, and Primarily Undergraduate). Third, the data were assessed according to location (four selected metropolitan areas vs. others). The second and third levels of analyses were performed with a view to uncovering potential trends. Each semantic differential question was submitted to a Pillai Trace multivariate test to find out whether there were statistically significant differences $(p<.05)$ by type and location, and if so, to a Tukey test to bring it down to the univariate level and identify where the significant difference was located. Out of the 89 questionnaires mailed to the university heads, a total of 48 replies were received, for a response rate of $54 \%$. This rate was achieved after one reminder to all and a second reminder to Medical/Doctoral institutions only, with the view of obtaining a more robust representation from that category where the return was initially low. Response rates by university types were the lowest among Primarily Undergraduate universities (28 out of 59 or $47 \%$ ), followed by Medical/Doctoral universities ( 8 out of 15 or $53 \%$ ), and the highest among Comprehensive universities (12 out of 15 or $80 \%$ ). Fourteen of the 48 responding universities indicated that they are located in Vancouver, Toronto, Montreal or Halifax. The other 34 universities declared themselves to be elsewhere." 
Table 1

\section{Proposed Sources of Funds in Operating Budget}

\begin{tabular}{|c|c|c|c|c|}
\hline Category & $\begin{array}{c}\text { All } \\
(n=47) \\
\%\end{array}$ & $\begin{array}{c}\text { Medical/ } \\
\text { Doctoral } \\
(\mathrm{n}=8) \\
\%\end{array}$ & $\begin{array}{l}\text { Comprehensive } \\
\qquad \begin{array}{c}(\mathrm{n}=10) \\
\%\end{array}\end{array}$ & $\begin{array}{c}\text { Undergraduate } \\
\qquad \begin{array}{c}(\mathrm{n}=29) \\
\%\end{array}\end{array}$ \\
\hline \multicolumn{5}{|l|}{ Sources } \\
\hline Government & 60 & 59 & 65 & 59 \\
\hline Tuition & 29 & 27 & 27 & 30 \\
\hline Corporations & 7 & 8 & 7 & 7 \\
\hline Other sources & 4 & 6 & 1 & 4 \\
\hline
\end{tabular}

\section{SUMMARY OF FINDINGS}

\section{General Fiscal Environment}

The university presidents were asked in what proportion each would source university revenue, based on considerations such as their own beliefs in social equity, cost sharing, and the government's capacity to pay. Table 1 summarizes their responses.

Across the three types of institutions, the suggested distribution was $60 \%$ from government, $29 \%$ from tuition, $7 \%$ from corporations, and $4 \%$ from endowments and other sources. Not unexpectedly the Medical/ Doctoral institutions placed a somewhat higher emphasis on financial support from "other benefactors" than did those of the Primarily Undergraduate, and particularly the Comprehensive universities. The difference among the three on this dimension is statistically significant $(\mathrm{F}=3.445 ; \mathrm{p}=.041)$. There was, however, consistency on certain items across the three types of institutions, wherever located. For example, the presidents were uniformly in agreement that faculty, students and the general public have limited awareness of the funding breakdown from key sources such as government, student tuition, and others including private donations (Table 2). At the same time, the data indicated that faculty and students in Primarily Undergraduate universities, and in particular those in 
Table 2

Fiscal Perspectives Shared Across Groups (no significant differences)

\begin{tabular}{|c|c|c|}
\hline (1) & $\begin{array}{c}\text { Mean } \\
\text { I }=\text { high } \ldots . .5=\text { low) }\end{array}$ & $\begin{array}{l}\text { Standard } \\
\text { Deviation }\end{array}$ \\
\hline \multicolumn{3}{|l|}{ Budget awareness } \\
\hline faculty* & 2.563 & .920 \\
\hline students* & 3.229 & .973 \\
\hline public* & 3.776 & .941 \\
\hline Higher Education a right ${ }^{\Delta}$ & 2.667 & 1.275 \\
\hline Tuition geared to earnings ${ }^{\Delta}$ & 2.490 & 1.190 \\
\hline Fee deregulation (all fees) $\Delta$ & 3.157 & 1.302 \\
\hline Fee increases gone too far ${ }^{\Delta}$ & 3.039 & 1.039 \\
\hline \multicolumn{3}{|c|}{ Note: ${ }^{*}$ Mid-point has a value } \\
\hline
\end{tabular}

non-metropolitan areas, were thought by university heads to have markedly greater knowledge about their institution's funding sources ( 2.357 versus an overall mean of 2.563 where 1 is "very positive"). Nonetheless, awareness on the part of faculty collectively was deemed to be little better than fair (Table 3) and was believed least present in Medical/ Doctoral universities (mean of 2.875). The general public was perceived to have a relatively low level of awareness and students were thought to be somewhere in between.On some of the other items there was more variability in responses across the different types of institutions, although these differences are not statistically different. For example, presidents of the Medical/Doctoral institutions disagreed with the view that higher education should be a public right, with a low individual price, whereas the other two groups were neutral or uncertain. The Medical/Doctoral respondents expressed support for tuition fees in professional programs to be geared to anticipated earnings but took no clear position on total fee deregulation. The heads of Comprehensive universities in particular were opposed to fee deregulation, although both they and the Primarily Undergraduate were non-committal on deregulation for professional programs. 
Table 3

\section{Fiscal Perspectives: Significant Differences Between Metropolitan and Non-Metropolitan locations}

\begin{tabular}{|c|c|c|}
\hline$(1=$ & $\begin{array}{l}\text { Mean } \\
\operatorname{igh} \ldots 5=\text { low) }\end{array}$ & F-Value \\
\hline Fee increases gone too far ${ }^{\Delta}$ & Metro: 3.467 & $3.802(\mathrm{p}=.057)$ \\
\hline & Non: $\quad 2.861$ & \\
\hline & All: $\quad 3.039$ & \\
\hline Budget Awareness & Metro: 3.071 & $6.788(p=.012)$ \\
\hline Faculty* & Non: $\quad 2.353$ & \\
\hline & All: $\quad 2.563$ & \\
\hline Budget Awareness & Metro: 3.786 & $7.342(\mathrm{p}=.009)$ \\
\hline Students* & Non: 3.000 & \\
\hline & All: $\quad 3.229$ & \\
\hline $\begin{array}{r}\text { Note: }{ }^{*} \text { Mid-point has a value } \\
\Delta \text { Mid-point means neutr }\end{array}$ & uncertain & \\
\hline
\end{tabular}

With respect to the general tuition spiral, there was a statistically significant difference between the responses of the non-metropolitan institutions and the metropolitan (see Table 3). The heads of universities in Vancouver, Toronto, Montreal and Halifax collectively disagreed that fee increases have gone too far ( 3.5 on a five point scale where 1 denotes strong agreement), whereas those in the non-metropolitan institutions were neutral or uncertain (2.9). (It should be noted here that fees at universities in the province of Quebec are constrained by government regulation and that in many institutions they do not constitute more than $15 \%$ of the total operating budget.)

\section{Accountability}

The survey instrument contained two items that relate to accountability. On both there was agreement (Table 4): more accountability for healthy enrolments should fall on academic units and faculty members, and value for money has not increased proportionately with tuition fees. 
Table 4

\section{Accountability: Responses Shared Across Groups}

\begin{tabular}{lcc}
\hline Item & $\begin{array}{c}\text { Mean } \\
(\mathbf{1}=\mathbf{h i g h ~} \ldots \mathbf{5}=\mathbf{l o w})\end{array}$ & $\begin{array}{c}\text { Standard } \\
\text { Deviation }\end{array}$ \\
\hline $\begin{array}{l}\text { Faculty accountable for } \\
\text { healthy enrolment* }\end{array}$ & 2.118 & .864 \\
\hline Less value for money* & 3.588 & .829 \\
\hline
\end{tabular}

Note: * Mid-point has a value

\section{Increased Corporate Involvement}

Whereas the foregoing section dealt with the fiscal environment, the next section focuses on the impact of increased links between universities and the corporate sector. The three groups of presidents, regardless of the location of their institutions, agreed that increased corporate involvement/partnering is putting an imprint on academic priorities as they relate to industry-relevant research (1.8 where 1 is "very positive"), and only slightly less a stamp on business and technology friendly programs ( 2 on the same scale). Yet in a related vein they held the view that the new links between academia and the corporate sector have negligible impact on arts-oriented programs. With regard to the effect of corporate involvement/ partnering on academic priorities in either research intensive or primarily teaching universities, the influence was seen to be mildly positive in the research intensive and virtually nil in primarily teaching institutions (Table 5). At the same time, when one considers regional universities (i.e. institutions, large or small, with a geographically defined focus), the Comprehensive universities viewed the impact to be significantly greater, in contrast to Medical/Doctoral or in particular to the Primarily Undergraduate (Table 6).

There were no significant differences among the three groups with respect to the perceived positive impact of government "challenge and matching" research support programs on any one of the creation of research centres, the pursuit of business and technology-friendly 
Table 5

\section{Corporate Influences: Responses Shared Across Groups} (no significant differences)

\begin{tabular}{llc}
\hline Item & $\begin{array}{c}\text { Mean } \\
(\mathbf{1}=\text { high } \ldots \mathbf{5}=\text { low })\end{array}$ & $\begin{array}{c}\text { Standard } \\
\text { Deviation }\end{array}$ \\
\hline $\begin{array}{l}\text { Corporate influence felt* } \\
\text { industry relevant research }\end{array}$ & 1.824 & .684 \\
$\quad$ research centres & 2.043 & .464 \\
$\quad$ bus/technology & 2.078 & .523 \\
$\begin{array}{l}\text { Programs } \\
\quad \text { arts-oriented programs }\end{array}$ & 3.020 & .678 \\
$\quad$ basic research & 2.980 & .949 \\
\hline $\begin{array}{l}\text { Academic priorities shaped* } \\
\quad \text { research-intensive Us } \\
\quad \text { primarily teaching Us }\end{array}$ & 2.388 & \\
\hline Increase student/client focus ${ }^{\triangle}$ & 2.875 & .786 \\
\hline
\end{tabular}

Note: ${ }^{*}$ Mid-point has a value (e.g., $3=$ no impact)

$\Delta$ Mid-point means neutral or uncertain

research, and the enhancement of Canadian competitiveness. Also there was a common view that the impact on basic research had been somewhat positive. Further, there was a shared sense that there is no impact on arts-oriented research, control over research findings, or on autonomy to set strategic directions. These findings applied across all institutions, both metropolitan and non-metropolitan.

The heads of the different groups differed significantly, however, in their collective perceptions as to whether private donations/ connections/ partnerships are widening the gap between basic and industry-relevant research. Heads of Primarily Undergraduate institutions regarded the gap to be growing to a much greater degree than did the Medical/Doctoral. Their collective perceptions also differed to a degree that approached statistical significance on several related dimensions. For instance, there was somewhat stronger agreement from Primarily Undergraduate institutions that a growing discrepancy exists in the way that faculty, as opposed to 
Table 6

Significant Differences by Type of Institution

\begin{tabular}{|c|c|c|c|}
\hline Item & $\begin{array}{r}\text { Mea } \\
\text { iigh ... }\end{array}$ & $\mathbf{n}=$ low) & F-Value \\
\hline Benefactors/other support* & $\mathrm{M} / \mathrm{D}:$ & $6.250 \%(\mathrm{n}=8)$ & $3.445(\mathrm{p}=.04)$ \\
\hline (excluding gov't, tuition & $\mathrm{C}:$ & $1.000 \%(n=10)$ & \\
\hline corporate) & $\mathrm{U}:$ & $4.276 \%(n=29)$ & \\
\hline & All: & $3.915 \%(n=47)$ & \\
\hline Corporate impact on & M/D: & 2.667 & $3.108(\mathrm{p}=.05)$ \\
\hline regional universities** & $\mathrm{C}:$ & 2.364 & \\
\hline & U: & 3.033 & \\
\hline & All: & 2.830 & \\
\hline Growing gap ${ }^{4}$ & M/D: & 3.250 & $3.981(\mathrm{p}=.025)$ \\
\hline basic vs. industrial rel. & $\mathrm{C}:$ & 3.000 & \\
\hline & $\mathrm{U}:$ & 2.290 & \\
\hline & All: & 2.628 & \\
\hline Emphasis on job market ${ }^{\triangle}$ & M/D: & 2.875 & $3.076(\mathrm{p}=.056)$ \\
\hline & $\mathrm{C}:$ & 1.917 & \\
\hline & $\mathrm{U}:$ & 2.200 & \\
\hline & All: & 2.255 & \\
\hline Emphasis on cutting edge & $\mathrm{M} / \mathrm{D}:$ & $26.143 \%(\mathrm{n}=7)$ & $4.140(\mathrm{p}=.023)$ \\
\hline research* & $\mathrm{C}:$ & $19.333 \%(n=10)$ & \\
\hline & U: & $14.039 \%(n=26)$ & \\
\hline & All: & $17.240 \%(n=43)$ & \\
\hline
\end{tabular}

Note: * Assigned portion of constant sum equalling 100\%

** Mid-point has a value

$\Delta$ Mid-point means neutral or uncertain 
the senior administrative officers, see the role of the university ( $F=$ $2.430 ; \mathrm{p}=.063$ ). The same can be said of differences between the way in which the faculty on the one hand, and the private sector on the other, define the university's role $(F=2.798 ; p=.071)$. Here respondents from the Comprehensive institutions and the Primarily Undergraduate were in equal agreement about the discrepancy. Overall the Medical/Doctoral presidents perceived less divergence on these issues among faculty, senior administrative officers, and the corporate sector. In similar vein, respondents from the Primarily Undergraduate also signalled an expanding gulf between arts-oriented on the one hand and business/technology areas on the other hand, but they were the only group to do so $(F=2.931$. $\mathrm{p}=.063$ ). One item which invites particular comment is the perceived gap between primarily teaching institutions and research intensive universities. This gap is believed by the Primarily Undergraduate respondents to be widening. The Comprehensive and Medical/Doctoral respondents were more non-committal. The last question in this section solicited opinions from the presidents on the influence of the private sector as an impetus for academic institutions to revisit the fundamental mandate/definition of universities, to place more emphasis on preparing students for the job market, and to provide a more student/ client focused environment. A significant difference was present in the responses on the topic of preparation for the job market, with respondents in the Comprehensive university group indicating the strongest interest in this element, and Medical/Doctoral the least. Responses on the other two questions were neutral or uncertain from all groups.

\section{Program Priorities for the Future}

The final three questions focused on institutional priorities today, and in the future, as perceived by the respondents. A follow-up question centred on the sense of urgency created by certain environmental forces, and a further supplementary one investigated key dimensions embraced by the University's mission. To be specific, Question 9 elicited present emphasis and recommended weight in future of certain emerging imperatives within undergraduate education, most notably: (1) technology; (2) internationalization; (3) co-op/ work study; (4) job training; and 
Table 7

Today's Emphasis vs Tomorrow's Imperatives by Type of Institution

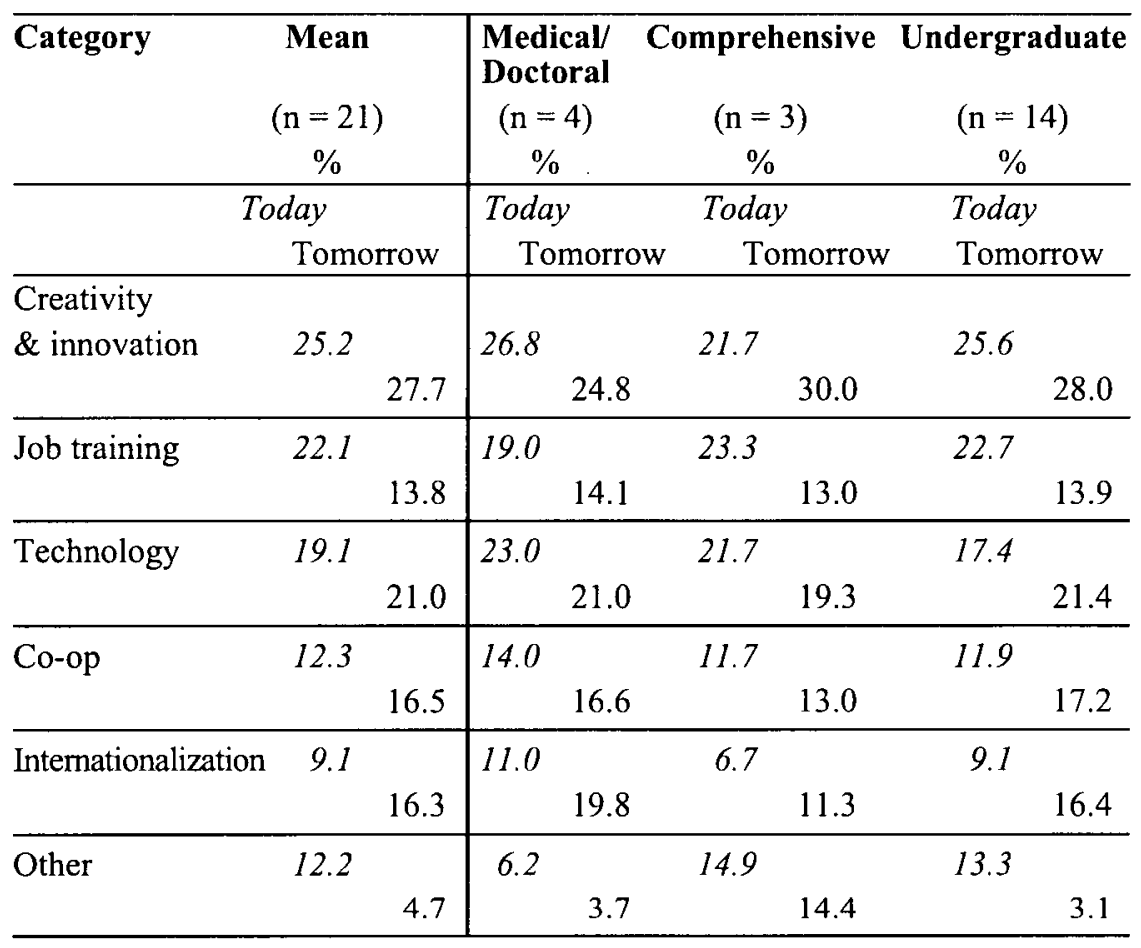

(5) creativity and innovation. Several respondents added "communication" as another imperative. From one other came "Culture" and from yet another, "General Knowledge." Table 7 summarizes how the heads of each type of institution captured today's picture. In decreasing order, today's emphasis was on fostering creativity and innovation, job training, technology, co--op studies, and internationalization. Their vision of the future still placed creativity and innovation at the top of the list but technology rose to second place. All types of institutions signalled a deemphasis on job training in the future (range of $-4.9 \%$ to $-10.3 \%$ ) and a slightly increased emphasis on technology. Their responses suggested that internationalization and co-op studies will also be on the rise across all 
Table 8

New Issues: Responses Shared Across Groups

(no significant differences)

\begin{tabular}{|c|c|c|}
\hline$(1=h$ & $\begin{array}{l}\text { Mean } \\
\text { igh } \ldots 5=\text { low) }\end{array}$ & $\begin{array}{l}\text { Standard } \\
\text { Deviation }\end{array}$ \\
\hline Build new economy* & 1.980 & .761 \\
\hline Be seen as economic engine* & 2.177 & .740 \\
\hline Keep core/freedom intact & 2.049 & 1.124 \\
\hline Need revisit core mandate ${ }^{\Delta}$ & 2.765 & .908 \\
\hline \multicolumn{3}{|l|}{ Program delivery mode ${ }^{\Delta}$} \\
\hline undergraduate & 2.471 & 1.065 \\
\hline graduate & 2.918 & 1.096 \\
\hline \multicolumn{3}{|c|}{ Note: ${ }^{*}$ Mid-point has a value } \\
\hline
\end{tabular}

types of institution, as well as creativity and innovation in Comprehensive $(+8.3 \%)$ and Primarily Undergraduate $(+2.4 \%)$ universities.

Analysis of the data from metropolitan vs. non-metropolitan respondents echoed similar trends, and hence the results are not tabulated in this article. Interestingly, presidents of non-metropolitan universities perceived a greater emphasis on creativity and innovation today $(9.6 \%$ more) than did metropolitan; however, metropolitan figures for the future close the gap. The data also suggested that university heads held the view that job training will be de-emphasized substantially in universities of all types, regardless of location $(-8.9 \%)$. At the same time, heads of the metropolitan institutions gave increased weight in future to co-op studies by almost $12 \%$. They also envisaged a growth in internationalization by $7.5 \%$. Collectively the respondents found this question about today's emphasis and tomorrow's imperatives the most difficult to answer. As seen below, all the presidents indicated some sense of urgency with regard to the thrust to "build the new, knowledge-based economy" (1.980) and the onus to "appear to your closest stakeholders 
Table 9

\section{Components of Institutional Emphasis by Type of Institutions}

\begin{tabular}{|c|c|c|c|c|}
\hline Components & $\begin{array}{c}\text { All } \\
(\mathrm{n}=43) \\
\%\end{array}$ & $\begin{array}{c}\text { Medical/ } \\
\text { Doctoral } \\
(\mathrm{n}=7) \\
\%\end{array}$ & $\begin{array}{l}\text { Comprehensive } \\
\qquad \begin{array}{c}(\mathrm{n}=10) \\
\%\end{array}\end{array}$ & $\begin{array}{l}\text { Undergraduate } \\
\qquad \begin{array}{c}(\mathrm{n}=26) \\
\%\end{array}\end{array}$ \\
\hline Critical thinking & 26.3 & 25.4 & 24.3 & 27.3 \\
\hline $\begin{array}{l}\text { Disciplinary } \\
\text { expertise }\end{array}$ & 22.9 & 22.6 & 18.5 & 24.6 \\
\hline Problem solving & 17.4 & 12.1 & 20.3 & 17.7 \\
\hline $\begin{array}{l}\text { Cutting edge } \\
\text { research }\end{array}$ & 17.2 & 26.1 & 19.3 & 14.0 \\
\hline Job training & 12.7 & 10.7 & 13.0 & 13.0 \\
\hline Other & 3.5 & 3.1 & 4.6 & 3.4 \\
\hline
\end{tabular}

to be an economic engine" (2.177). Nevertheless, the counter impetus to "protect the integrity of the university's long-standing mandate as the centre of intellectual activity, unconstrained by the agenda of the day," emerged just as strongly (2.049). Issues around modality for the delivery of degree programs, whether undergraduate (2.471) or graduate (2.918), were less of a concern.

The final question relates to the institution's mission. The presidents responses (Table 9) affirmed, not surprisingly, that the component within the institutional mission that distinguishes Medical/Doctoral institutions from the others is "cutting edge research" $(p=.023)$. For those in Medical/Doctoral institutions, cutting edge research was accorded a weight of $26.1 \%$ and was the leading dimension, with critical thinking $(25.4 \%)$ a close second. By contrast, they placed considerably less weight on problem-solving skills than the heads of the other two types of universities. While the difference in the weight attached to cutting edge research is significant, both between metropolitan and non-metropolitan institutions $(p=.017)$ and between the three types of institutions $(p=.023)$, there was no difference in the weight granted to fostering 
critical thinking. It is noteworthy that respondents from all types of institution put great emphasis on this latter dimension. Indeed, responses across all types of institution indicated that fostering critical thinking ranks as the most important dimension of all (26.3\%), followed by transmitting disciplinary expertise (22.9\%), with problem solving and cutting-edge research both hovering around $17 \%$, and job training at $12.7 \%$. It is notable that the least prominent dimension among those mentioned was job training. Relative to critical thinking, the presidents gave job training only half as much weight (13\%). At the same time, when the responses of presidents in the non-metropolitan areas are considered, emphasis upon job training (14\%) was greater than in the metropolitan, and this difference is almost statistically significant $(p=.072)$.

\section{ANALYSIS AND INTERPRETATION}

University presidents are beleaguered by the reality that government has reduced its support for universities and that tuition fee increases have not closed the gap. Governments and society place large expectations upon universities to drive the so-called "New," knowledge-based economy (e.g., Clark, 1998; Organization for Economic Cooperation and Development, 1998; van Vught, 2000). Preparation of appropriately equipped workers and the enhancement of Canadian economic competitiveness are imperatives thrust upon universities whose presidents may fear justifiably that alternative providers will respond if they do not. Further, the federal government and some provincial governments have seized upon "challenge and matching" programs to expand university links with industry in targeted areas, typically science and technology, health, and the environment.

The above results indicate the degree to which university presidents think along similar lines, in spite of obvious distinctions across types of institutions. The decline in government support has put pressure on their institutions to remedy the gap in other ways. It appears that the role which tuition fees play in university revenues (up to $40 \%$ in many artsoriented institutions) is one on which university heads take no strong stand. Presidents of metropolitan universities tend to be less sympathetic 
to the view that education at a low cost to the student is a public right. The Medical/Doctoral universities mildly disagreed that fee increases have gone too far, perhaps because they have the luxury of student numbers coupled with the fact that they are mostly the ones offering the professional programs which are quick generators of high income for graduates. Respondents from the other two types of institution were noncommittal. None of the three groups of presidents favoured full deregulation of tuition fees, with the Comprehensive universities being the most opposed. In all likelihood the harsh reality of budget stringency will continue to dictate fee levels in contexts where they are not constrained by legislation. University heads appear to hope that attractive academic programs, coupled with student debt reduction strategies, will offset the negative effect of escalating fees and sustain the principle of accessibility in institutions where this prevails.

Tuition fees elicited strong comment. Stated unequivocally by respondents from all three types of institution in all settings is the view that value for money has not increased proportionately with the rise in tuition fees. This leads to the question: Are students getting their money's worth?

Another area of agreement was that faculty members have a responsibility to ensure healthy enrolments within their programs. Yet university heads also think that faculty members know relatively little about the university's operating budget, which is fed by enrolment. Still they believe them to be more knowledgeable than either students or the public at large. According to the respondents, none of these stakeholder groups tends to be well informed on the workings of the budget in Medical/Doctoral institutions. The general perception was that relative to other institutions, more is known about the budget in Primarily Undergraduate universities in non-metropolitan settings. It is likely that tuition is a greater subject of debate in these latter institutions, and that this debate occurs against the backdrop of budget setting.

In the data one finds that presidents in all contexts are conscious of the pressure for universities to play a major role in attaining Canada's place in the global economy. Arguably, those pressures emanate not just from the larger society in the form of government "challenge and matching" 
opportunities but also from their own constituencies and stakeholders whom they are closely linked to, namely their Boards and no doubt the politicians and other leaders in their locales. Given their status as community leaders, they would be hard pressed to reject an agenda that links national competitiveness with institutions of higher learning that are recognized as economic engines. Nor would it be surprising in this context that, even without the impetus of government "challenge and matching" initiatives, there would be an emphasis on the program areas that are cornerstones in this new economy, namely those related directly and indirectly to science and technology, including the environmental, health and management fields.

Hence, university presidents are faced with pressures and opportunities which they appear to view as encouraging corporate involvement/ partnering. If one had to characterize the response of university heads to the pressures of the new level of corporate involvement/ partnering, one might say that they have made peace with this phenomenon. All three groups of university presidents are quick to say that arts-oriented programs are NOT affected by this new current, and that basic research, IF affected, is only mildly so and in a positive direction. Nonetheless, they share the view that research centres and business and technologyfriendly programs have flourished in a fiscally strained situation.

One might posit that research-intensive institutions are the most impervious to the influence of the corporate agenda. Most basic research is done in the Medical/Doctoral institutions where the emphasis is on "cutting edge" activity. This focus attracts researchers of renown, and research dollars, and is shared by faculty and administration alike. This dimension also brings promising students to the door regardless of tuition cost. In short, it may be argued that there is a singleness of purpose that is characteristic of the research-intensive institutions, erosion of which is buffered by a strongly held belief system. One would expect, too, that the impact of the corporate agenda on the institution's research and program emphasis might reflect the relative level of research funding from various sources. The example that follows suggests that substantially more effect might occur in the primarily teaching institution responding to the research imperatives of the regional economy. The 
University of Toronto, a research-intensive Medical/Doctoral institution, recently received $\$ 17.4$ million through the (Province of) Ontario Research and Development Challenge Fund (ORDCF) to support five separate projects in assorted domains. Industry contribution was required. The same university also received $\$ 39.5$ million from Canada's Natural Sciences and Engineering Research Council (NSERC), the primary vehicle of federal government support for basic scientific research. By comparison, Laurentian University in northeastern Ontario, a regional university with a professional and mining profile, was awarded $\$ 2.2$ million for one ORDCF project and $\$ 1.4$ million from NSERC. A quick calculation shows that the University of Toronto received only 7.9 times more ORDCF funding but 28.2 times more NSERC funding than Laurentian University. If Medical Research Council (now Canadian Institutes of Health Research) funding were added to NSERC money, the 28.2 times would be drastically higher. Suffice it to say that the proportion of research dollars from such "challenge and matching" funds relative to all research funding is very different in the two settings. Further, it would seem reasonable to expect that the relative impact of such funds on the overall agenda of an institution might vary accordingly.

Presidents of the Primarily Undergraduate institutions fear that the distinction between themselves and the research intensive institutions is increasing. The data at hand suggest that the Primarily Undergraduate institutions are much more aware of operating budgets and tuition fee issues, and of gaps between the agenda of faculty on the one hand and that of senior administrators on the other with regard to the fundamental role of the university. Respondents from the Primarily Undergraduate institutions, particularly those in non-metropolitan locations, affirm the need to prepare students for the job market almost as staunchly as do the Comprehensive. One might conclude that their stakeholders are putting pressure on the senior administrative cadre to prepare students for the "new" economy. It is noteworthy, however, that presidents of all types of institutions are conscious of job-training (interestingly, the most consistent level of commitment - i.e., comparing projected to current - was found in the Medical/Doctoral universities, and is anticipated to be at a slightly higher future level than in the other two types of institution). 
Also, respondents in all three groups listed technology as the third emphasis and yet not far behind creativity and innovation in first place with job training as second at this time. This suggests that job training has to fit with the demands of a technological era. These heads indicated that technology will become even more important in the future. They raise it to second place, only behind fostering creativity and innovation which is still the leading emphasis. It would seem that the importance attached to job training, by then considerably diminished, will be more closely synchronized with the institutional mission (see Table 9). One might deduce that heads of universities envisage that other priorities will overtake job training per se in the future, with creativity, innovation and technological competencies becoming ascendant. Arguably these competencies mesh with the concept of the "economic engine."

Essentially university presidents appear to have concluded that they cannot say "no" to the new imperatives that come with the global economy. At the same time they must tread a fine line, either out of conviction or because the concept of academic freedom, central to the unfettered quest for truth, is seen by some of their key stakeholders (in particular certain members within the faculty and student body) to be endangered by the intrusion of the corporate presence. All three groups of respondents affirmed allegiance to the search for knowledge for its own sake. They asserted, too, that there was no control over research outcomes, nor over university autonomy to set strategic directions.

All universities do research, including the primarily undergraduate institutions. Career advancement rests mainly on scholarly output. It could be argued that Comprehensive universities have the most to gain from partnering with industry. The Comprehensive university attempts to offer a wide range of undergraduate programs, and also a selection of graduate, that reflect the internal strengths of the institution. In many cases the academic strengths within the institution parallel salient features of the region on which its economy depends. These institutions do not expect the same high level of support from "benefactors." Also they are typically hungrier for research dollars than the research-intensive universities. One could argue that funding opportunities which allow them to seek regional partners and expand the expertise needed to 
sustain the regional economy, and where feasible make it globally competitive, appeal to university management and to individual researchers as a win-win scenario strengthening their ties with regional stakeholders and enabling their institution to be seen as the economic engine expected by the society around them. Economic development strategies in regional economies often depend heavily on the participation of the university as a pivotal player. This has probably long been the case, but now the expectations are explicit - industry and community leaders turn to the university for assistance to support and expand the region's economy. Not surprisingly it is the Comprehensive universities, many of which qualify as "regional universities," that indicate the largest impact of corporate involvement/ partnering in terms of emphasis on industryrelevant research. Combined with the research thrust will be an impact on programming.

\section{CONCLUSIONS}

In summary, it is reported elsewhere that some faculty members are skeptical concerning the degree to which university administrators are committed to the academy's long standing mandate as the centre of intellectual activity unconstrained by the agenda of the day (e.g., Currie, 1998; Fisher \& Rubenson, 1998). The literature informs us that some academics worry as they see the ascendance of an agenda driven by the corporate sector, and backed by the government at a time when universities are hungry. In our study it is the heads of the Primarily Undergraduate institutions that expressed the greatest concern in this respect. Further, society in general is pushing the universities to take the lead in achieving global competitiveness in a knowledge based economy. Students and parents are demanding job-relevant programs. The data indicate that university presidents take the view that faculty members should shoulder more responsibility for enrolments. While these may be uneasy times within the institutions, it would seem that university administrators do not see that increased interaction with the private sector will change their view of the fundamental mandate/ definition of "the university." Nor do they perceive that such interaction is likely to 
spur any shift of note to a more client-focused environment. Similarly, their sights are not set on competing against new modes of delivery by alternative service providers (e.g., Phoenix U). The common purpose that all endorse is the fostering of critical thinking. It would appear from the data that they are striving to strike a balance between the pursuit of truth on the one hand, and shaping the populace to function effectively in the new economy on the other, all the while with an eye on the bottom line. Seemingly they recognize that firms would like universities to offer "just in time" delivery of training, but at the same time universities must promote a learning culture "for its own sake." One might deduce that university presidents would affirm that co-operation between ivory tower and market place is, and will remain, more of a marriage de raison than a marriage de passion.

\section{References}

Abele, F. (1992). The politics of competitiveness. In F. Abele (Ed.), How Ottawa spends, 1992-93. Ottawa, ON: Carleton University Press.

ACST - (Prime Minister's) Advisory Council on Science and Technology. (1999). Public investments in university research. Ottawa, ON: Government of Canada.

AUCC - Association of Universities and Colleges of Canada. (1999). Trends. Ottawa, ON: Author.

BCLFDB - British Columbia Labour Force Development Board. (1995). Training for what? Victoria, BC: Author.

Buchbinder, H., \& Newson, J. (1990). Corporate-university linkages in Canada: Transforming a public institution. Higher Education, 20(4), 355-379.

Buchbinder, H., \& Rajagopal, P. (1993). Canadian universities and the politics of funding. In P. Altbach \& D. Johnstone (Eds.), The funding of higher education: International expenditures, (pp. 271-285). New York, NY: Garland Publishing.

Buchbinder, H., \& Rajagopal, P. (1995). Canadian universities and the impact of austerity on the academic workplace. In J. Smythe (Ed.), Academic work: The changing labour process in higher education, (pp. 60-73) . London: Society for Research in Higher Education and Open University Press. 
Cassin, M., \& Morgan, J.G. (1992). The professoriate and the marketdriven university: Transforming the control of work in the academy. In W. Carroll, L. Christiansen-Rufman, R. Currie, \& D. Harrison (Eds.), Fragile truths: 25 Years of sociology and anthropology in Canada, (pp. 247-260). Ottawa, ON: Carleton University Press.

CAUBO - Canadian Association of University Business Officers. (1999). Financial statistics of universities and colleges, 1997-1998. Ottawa, ON: Statistics Canada.-

CAUT - Canadian Association of University Teachers. (1999). CAUT deplores final expert panel report. CAUT Bulletin, 46(6), 1.

Clark, B.R. (1998a). The entrepreneurial university: Demand and response. Tertiary Education And Management, 4(1), 5-16.

Clark, B.R. (1998b). The entrepreneurial university. Berkeley, CA: University of California Press.

Currie, J. (1998). Introduction, and globalization as an analytical concept and local policy responses. In J. Currie \& J. Newson (Eds.), Universities and globalization: Critical perspectives, (pp. 1-20). Thousand Oaks, CA: Sage Publications.

Currie, J., \& Vidovich, L. (1998). Micro-economic reform through managerialism in American and Australian universities. In J. Currie \& J. Newson (Eds.), Universities and globalization: Critical perspectives, (pp. 153-172). Thousand Oaks, CA: Sage Publications.

De la Mothe, J. (1998). Government science and the public interest. In G. Doern (Ed.), Government, science and global change, (pp. 31-48). Toronto, ON: University of Toronto Press.

Dudley. (1998). Globalization and education policy in Australia. In J. Currie \& J. Newson (Eds.), Universities and globalization: Critical perspectives, (pp. 21-44). Thousand Oaks, CA: Sage Publications.

Dupré, S. (1998). Role of research is changing. University Affairs, December, p. 24.

Dwyer, V. (1997). Academia Inc. Maclean's, November 24, 66-71.

Etzkowitz, H., \& Leydesdorff, L. (Eds.). (1977). Universities in the global knowledge economy: A triple helix of academy-industry-government relations. London: Cassell.

Fairweather, J. (1988). Entrepreneurship and higher education. Washington, DC: Association for the Study of Higher Education.

Fallis, G. (1998). A call to Academia: Champion the liberal arts. Ontario Confederation of University Faculty Association Forum, Fall Issue, 6-7, 23. 
Fisher, D., \& Rubenson, K. (1998). The changing political economy: The private and public lives of Canadian universities. In J. Currie \& J. Newson (Eds.), Universities and globalization: Critical perspectives, (pp. 77-98). Thousand Oaks, CA: Sage Publications.

Florida, R. (1995). Toward the learning region. Futures, 27( 5), 527-536.

The Globe and Mail. (1999). Higher tuition fees are good for university students. August 28. Toronto, ON: Author.

Government of Québec. (1996). The state of education in Québec, 1995-1996. Québec, QC: Author.

Grigoroff, I. (1998). University spin-offs make it big time. University Affairs, June/July Issue, 11-14.

Johnson, A.F., McBride, S., \& Smith, P.J. (1994). Continuities and discontinuities: The political economy of social welfare and labour market policy in Canada. Toronto, ON: University of Toronto Press.

Lacroix, R., \& Martin, F. (1987). Les conséquences de la décentralisation régionale des activités de $R-D$. Report submitted to the Conseil de la science et de la technologie, Québec, QC: Gouvernement du Québec.

Maillat, D., \& Vasserot, J.Y. (1986). Conditions économiques et territoriales de la revitalisation des anciennes régions industrielles. Actes de la Conférence des technologies nouvelles de développement régional de l'ASRDLF, Paris, 256-266.

(Manitoba) University Education Review Commission. (1993). Postsecondary education in Manitoba: Doing things differently. Winnipeg. MB: Author.

Marginson, S. (1997). Markets in education. St. Leonard: Allyn and Bacon.

Newson, J. (1992). The decline of faculty influence: Confronting the effects of the corporate agenda. In W. Carroll, L. Christiansen-Rufman, R. Currie, \& D. Harrison (Eds.), Fragile truths: 25 Years of sociology and anthropology in Canada, (pp. 227-246) . Ottawa, ON: Carleton University Press.

Newson, J. (1994). Subordinating democracy: The effects of fiscal retrenchment and university-business partnerships on knowledge creation and knowledge dissemination in universities. Higher Education, 27(2), 141-161.

Newson, J. (1998). Conclusion. In J. Currie \& J. Newson (Eds.), Universities and globalization: Critical perspectives, (pp. 295-313). Thousand Oaks, CA: Sage Publications.

Newson, J., \& Buchbinder, H. (1988). The university means business: Universities, corporations and academic work. Toronto, ON: Garamond Press. 
Nova Scotia Council on Higher Education. (1996). Government support of universities in Nova Scotia: A proposal for a new funding formula. Halifax, NS: Author.

Ontario Council on University Affairs. (1995). 21st Annual Report. Toronto, ON: Author.

Organization for Economic Development. (1998). Science, technology and industry outlook. Paris: Author.

Polster, C. (1994). Compromising positions: The federal government and the reorganization of the social relations of Canadian academic research. Unpublished doctoral dissertation. Toronto, ON: York University.

Schumpeter, J.A. (1954). History of economic analysis. London: George Allen Unwin.

Shuchman, M. (1998). Blame it on the universities. The Globe and Mail, December 29.

Slaughter, S., \& Leslie, L. (1997). Academic capitalism: Politics, policies, and entrepreneurial university. Baltimore, MD: John Hopkins University.

Soley, L.C. (1996). Leasing the ivory tower: The corporate takeover of academia. Boston, MA: South End Press.

Statistics Canada. (1999). Weighted average tuition fees for Canadian students by faculty and province, 1972-73 to 1998-1999. Ottawa, ON: Author.

Tapper \& Salter. (1995). The changing idea of university autonomy. Studies in Higher Education, 20( 1), 59-71.

van Vught, F. (2000). Innovative universities: Challenges and perspectives. Paper presented at the International Seminar on University Governance and Management, Barcelona, Spain. 